\title{
Inflation Led Import or Import Led Inflation: Evidence from Bangladesh
}

\author{
Dewan Muktadir-Al-Mukit ${ }^{1}$, A. Z. M. Shafiullah' ${ }^{2}$ Md. Rizvy Ahmed ${ }^{3}$
}

${ }^{1}$ Lecturer, Faculty of Business Administration, Eastern University, Dhaka, BANGLADESH

${ }^{2}$ Assistant Professor, Department of Statistics, Biostatistics and Informatics, University of Dhaka, Dhaka, BANGLADESH.

${ }^{3}$ Lecturer, Faculty of Business Administration, Eastern University, Dhaka, BANGLADESH

\begin{abstract}
This study investigates the relationship between inflation and import for the economy of Bangladesh over the sample period of 2000 to 2011. This study used different econometric techniques of measuring the long and short term relationship between variables. The Johansen Cointegration test is used to determine the existence of a long term relationships between study variables. The normalized Cointegrating coefficients are found statistically significant and show a stable and positive relationship between study variables. The short run interactions are similar to the long run relationships. The estimated error correction coefficient indicates that 0.6 percent deviation of the inflation rate from its long run equilibrium level is corrected each period where such correction rate for import is 24 percent. Finally, Granger causality analysis suggests the existence of a unidirectional causality running from Inflation to import.
\end{abstract}

Keywords: Inflation, Import, Cointegration, VECM, Granger Causality JEL Classification Code: E31

\section{INTRODUCTION}

$\mathrm{I}$ nflation is considered as one of the major macroeconomic challenges for any economy. In an open economy, inflation is affected by international trade situation where import condition plays a vital role. "The availability of imports can affect domestic inflation directly via the prices of these imports included in the price index, and indirectly through competition with domestic goods and services" (Dexter et al. ,2005). So, it is necessary to determine the relationship of inflation with international trade condition.

Existences of excess aggregate demand results demand pull inflation where upward pressure of production costs results cost-push inflation. The relationship between inflation and import can be explained in two ways. One is inflation led import and another one is import led inflation or imported inflation. When the demand is higher than domestic output then the prices of good and services is expected to rise. This mismatch between demand and supply condition is handled by availing import policy. On the other hand, a rise in imports will cause depreciation in the exchange rate. This tends to increase inflationary pressure through making import costly. Moreover, when a country imports raw material then depreciation of local currency or appreciation of foreign currency makes import expensive and subsequently the cost of production for goods increases due to a rise in price of raw materials. So, higher import tends to increase inflation.

\section{Literature Review}

A number of studies focus on the dynamic relationship of inflation with import. The study of Ulke et al. (2011) uses

Copyright $(92$ 2013, Asian Business Consortium | ABR univariate Cointegration test, Error Correction model, and Granger causality to investigate the relationship between inflation and import volume for the Turkish economy over the period of 1995 to 2010. The study shows a longrun and dynamic relationship between inflation and import. A unidirectional causality from import to inflation is also found in that study. On the context of Nigerian economy for the period of 1970 to 1995, the study of Abidemi and Malik (2010) reveals that imports have positive relationship with inflation rate while exchange rate is indirectly associated to inflation. Lim and Papi (1997) have examined the determinants of inflation in Turkey economy for 1970 to 1995 . Their Cointegration analysis shows that money, wages, prices of exports and prices of imports have positive influence on domestic price level where as exchange rate exerts inverse effect on the domestic price level. In the US economy context the study of Dexter et al. (2005) shows that imports have a negative relationship with inflation and exports have a positive relationship with inflation. Khan and Gill (2010) studied on the determinants of inflation in Pakistan for the period of 1970 to 2007. They conclude that depreciation of exchange rate and increases in the value of imports contribute positively to the inflation.

Taslim (1982) attempted to examine the inflationary process in Bangladesh for 1960 to 1980. The findings indicate that any devaluation of the domestic currency is followed by an almost equal proportionate increase in the rate of inflation. The empirical test of Begum (1991) shows that the significant variables for inflation in Bangladesh are agricultural and import bottlenecks, government expenditure, rate of interest, wage rate, bank credit and expected 
inflation. Haque and Emran (1992) concluded that the ratio of imports to total food availability significantly affected the inflation in Bangladesh. Majumder (2006) discussed about inflation in Bangladesh from supply side perspective. He concludes that among supply side factors, import price index is the most significant variable. The study of Kanam and Rahman(1995) indicates that among a number of supply side variables- import price and money wages affect the inflation significantly and positively while remittance is found insignificant in forecasting inflations in Bangladesh.

\section{Data \& Methodologies}

The study attempts to determine the relationship between inflation and import. The data set comprises of monthly time series data for Bangladesh over the total 144 sample periods of January, 2000 to December, 2011. The sources include Global Economic Monitor released by the World Bank. Inflation is measured in terms of Consumer Price Index (CPI) which reflects change in the cost to the average consumer of acquiring a basket of goods and services. Import of goods and services is measured in terms of constant 2000 U.S. millions dollars. All data are transformed in logarithms form. LCPI is the natural logarithm of CPI and LIMPORT is natural logarithm of real import.

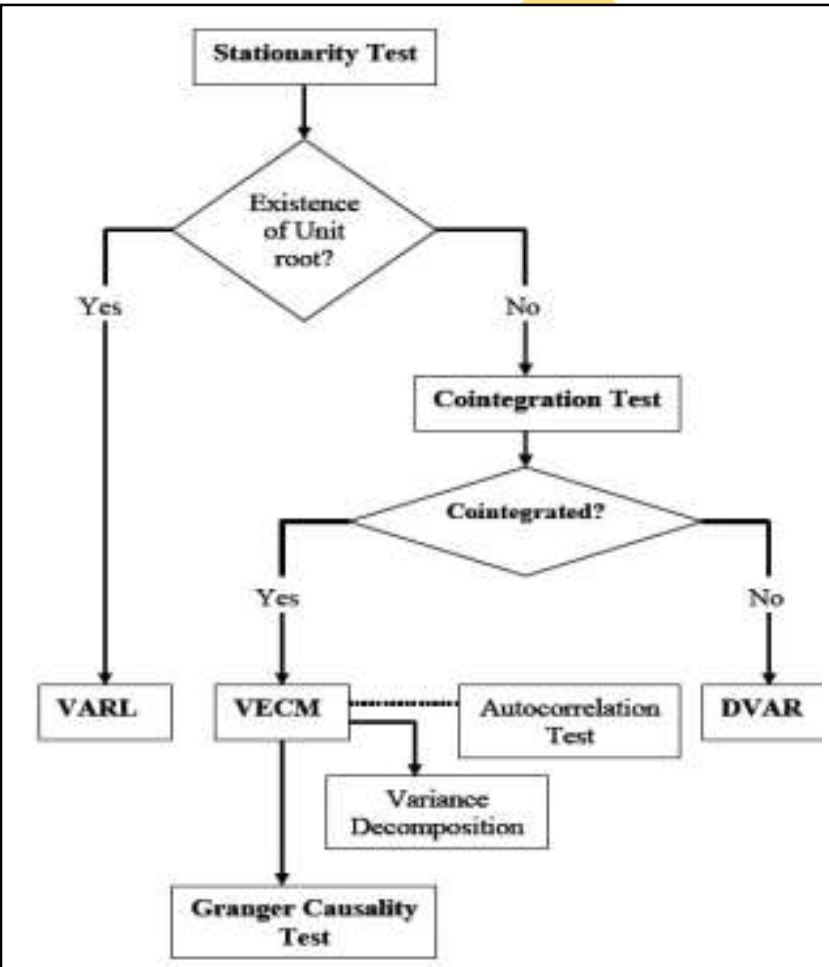

Fig. 1. Methodology of the study

In order to avoid a spurious regression situation the variables in a regression model must be stationary or cointegrated. If the data are stationary at level then we can proceed with Vector Autoregressive in the level data (VARL). But if the data is stationary at first difference then we will proceed with Cointegration test. If there is at least one cointegrating relationship among the variables, then the causal relationship among the variables can be determined by estimating the Vector Error Correction Model (VECM). Otherwise we will proceed with Vector Autoregressive in First differentiated data (DVAR). If there is a co-integration vector between inflation and import, there must be causality among variables at least in one direction (Granger, 1986). The final step of our analysis is to test for causality between the variables. The results are based on Granger causality test. Besides common econometric models we use a number of additional tests in analyzing statistical phenomenon of these variables comprises of Serial Correlation Lagrange Multiplier (LM) test, Variance Decomposition and Impulse Response Function (IRF). All the data have been processed using Eviews-7 software. Figure 1 shows the methodology we use.

\section{EmpIRICAL Findings}

\subsection{Stationarity Test}

To check for non-stationarity property, the data are subjected to Augmented Dickey and Fuller (ADF) test. ADF is performed by adding the lagged values of the dependent variable $\Delta \mathrm{Y}_{\mathrm{t}}$. The following regression is for ADF test purpose:

$\Delta \mathrm{Y}_{\mathrm{t}}=\beta_{1}+\beta_{2} \mathrm{t}+\delta \mathrm{Y}_{\mathrm{t}-1}+\alpha_{\mathrm{i}} \Sigma \Delta \mathrm{Y}_{\mathrm{t}-\mathrm{i}}+\varepsilon_{\mathrm{t}}$

Where $\varepsilon_{\mathrm{t}}$ is a white noise error term an $\Delta \mathrm{Y}_{\mathrm{t}-1}=($ $\mathrm{Y}_{\mathrm{t}-1}-\mathrm{Y}_{\mathrm{t}-2}$ ) and so on are the number of lagged difference term which is empirically determined. Using Schwarz Information Criterion (SIC) the lag length is selected automatically by E-views software. The null hypothesis of ADF test states that a variable is nonstationary and the null hypothesis of non-stationary is rejected if the calculated ADF statistics is less than the critical value. The Table 1 shows ADF test statistic used to examine the null of a unit root in the CPI and import data.

TABLE 1

Results of ADF test

\begin{tabular}{|l|c|c|}
\hline \multirow{2}{*}{ Variables } & \multicolumn{2}{|c|}{ ADF Test Statistic } \\
\cline { 2 - 3 } & Level & First difference \\
\hline LCPI & -2.605670 & $-12.16135^{* * *}$ \\
\hline LMMPRT & -2.247040 & $-10.95753^{* * *}$ \\
\hline
\end{tabular}

Note: ${ }^{* * *}$ indicates statistically significant at the $1 \%$ level

The results in Table 1 clearly indicate that ADF tests fail to reject the null of non-stationary for LCPI and LIMPORT both at level. After first differencing the result shows that LCPI and LIMPORT became stationary at the $1 \%$ significant level, implying that these variables are integrated of order 1 that is I(1). The figure 2 shows stationarity trend after first differencing the variables. 


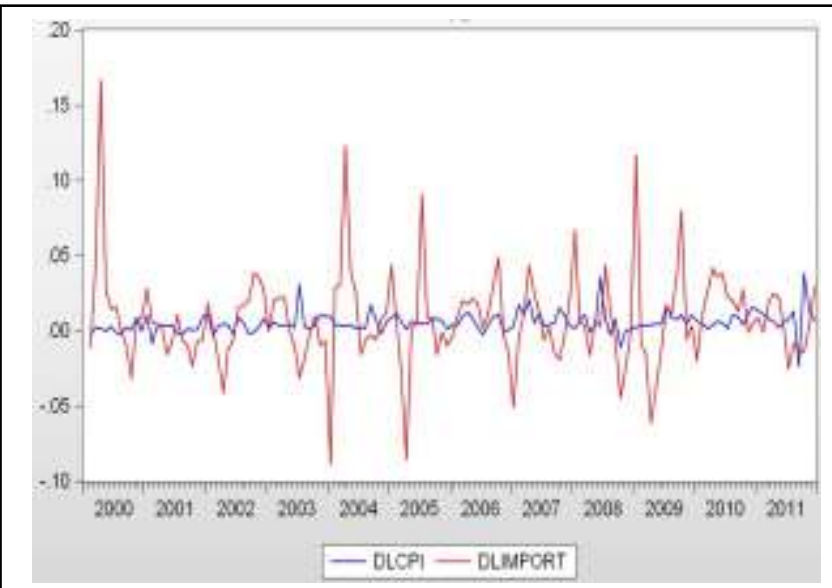

Fig. 2. Trend with stationary

\subsection{Testing Cointegration}

The concept of Cointegration is that non-stationary time series are cointegrated if a linear combination of these variables is stationary. Cointegration, an econometric property of time series variables, is a precondition for the existence of a long run or, equilibrium economic relationship between two or more variables having unit roots. Two or more random variables are said to be cointegrated if each of the series are themselves non-stationary, but a linear combination of them is stationary (Engle and Granger, 1987). Since the variables are considered to be I(1), the Cointegration method is appropriate to estimate the long run relationship between variables. For the purpose of testing Cointegration we have chosen the Johansen procedure. To explore the number of cointegrating vectors, Maximal Eigenvalue and Trace statistics both have been used. The results of Trace statistics and Maximum Eigenvalue are shown in Table 2 and Table 3 respectively.

TABLE 2

Unrestricted Cointegration Rank Test (Trace)

\begin{tabular}{|c|c|c|c|c|}
\hline \multicolumn{2}{|c|}{ Hypothesized } & \multirow{2}{*}{$\begin{array}{c}0.05 \\
\text { Critical Value }\end{array}$} & Prob.** \\
\cline { 1 - 2 } No. of CE(s) & Eigenvalue & Trace Statistic & C. & \\
\hline None ${ }^{*}$ & 0.175260 & 35.52822 & 15.49471 & 0.0000 \\
\hline At most $1^{*}$ & 0.057563 & 8.359321 & 3.841466 & 0.0038 \\
\hline
\end{tabular}

Trace test indicates 2 cointegrating eqn(s) at the 0.05 level

* denotes rejection of the hypothesis at the 0.05 level

**MacKinnon-Haug-Michelis (1999) p-values

TABLE 3

Unrestricted Cointegration Rank Test (Maximum Eigenvalue)

\begin{tabular}{|c|c|c|c|c|}
\hline \multicolumn{2}{|c|}{ Hypothesized } & \multirow[b]{2}{*}{ Max-Eigen Statistic } & \multirow{2}{*}{$\begin{array}{c}0.05 \\
\text { Critical Value }\end{array}$} & \multirow[b]{2}{*}{ Prob. ${ }^{n A}$} \\
\hline No. of $\mathrm{CE}(\mathrm{s})$ & Eigenvalue & & & \\
\hline None* & 0.175260 & 27.16890 & 14.26460 & 0.0003 \\
\hline At most $1^{*}$ & 0.057563 & 8.359321 & 3.841466 & 0.0038 \\
\hline
\end{tabular}

Max-eigenvalue test indicates 2 cointegrating eqn(s) at the 0.05 level

* denotes rejection of the hypothesis at the 0.05 level

**MacKinnon-Haug-Michelis (1999) p-values

Copyright (C) 2013, Asian Business Consortium | ABR
The Trace statistic and Maximal Eigen statistic both identified two cointegrating vectors. The presence of Cointegration implies the existence of a stable long run relationship between inflation and import. The normalized Cointegrating coefficients are estimated as reported in Table 4. The significant coefficient sign implies that in the long run the relationship between inflation and import is positive.

TABLE 4

Cointegrating Equation

\begin{tabular}{|c|c|}
\hline Cointegrating Equation & CointEq1 \\
\hline \hline LCPI(-1) & 1.000000 \\
\hline LIMPORT(-1) & -0.878279 \\
& $(0.03456)$ \\
& {$[-25.4136]$} \\
\hline C & 1.489646 \\
\hline
\end{tabular}

Note: Standard errors in ( ) \& t-statistics in [ ]

\subsection{Vector Error Correction Model}

As we find cointegrating relationship between study variables so we will proceed with Vector Error Correction Model (VECM). Though Cointegration affirms a stable long run relationship between the variables but in the short run this equilibrium may not exist. The Error Correction Mechanism explains short run adjustments towards long run relationship between the variables. It provides information about the speed of adjustment to long run equilibrium and avoids the spurious regression problem (Engle and Granger, 1987).The results of VECM were shown in Table 5.

TABLE 5

Error Correction Model

Vector Error Correction Estimates

Sample (adjusted): 2000M03 2011 M12

Included observations: 142 after adjustments

\begin{tabular}{c|c|c}
\hline Error Correction: & $\Delta$ LCPI & $\Delta$ LIMPORT \\
\hline ECM $_{t-1}$ & -0.006065 & 0.245189 \\
& {$[-0.53577]$} & {$[5.57391]$} \\
\hline \hline$\Delta$ LCPI $(-1)$ & -0.017794 & -0.032828 \\
& {$[-0.21070]$} & {$[-0.10003]$} \\
\hline \hline$\Delta$ LIMPORT $(-1)$ & -0.023393 & 0.411433 \\
& {$[-1.22609]$} & {$[5.54922]$} \\
\hline \hline$C$ & 0.005671 & 0.004736 \\
& {$[7.53947]$} & {$[1.62026]$} \\
\hline
\end{tabular}

Note: Figures in parenthesis represent the t-statistics

The estimated error correction coefficient indicates that about 0.6 percent deviation of the CPI from its long run equilibrium level is corrected each period in the short run, while the gaps in the import close by about 24 percent. Before making any further conclusions we test the residuals for serial correlation. Here we will test the null hypothesis of $\mathrm{H}_{0}=\mathrm{No}$ Autocorrelation against $\mathrm{H}_{1}=$ Autocorrelation. Based on the LM test from Table 6 we cannot reject the null hypothesis of no serial correlation at the $5 \%$ level of significance. 
TABLE 6

The results of the LM Autocorrelation test

\begin{tabular}{c|c|c}
\hline Lags & LM-Stat & Prob \\
\hline 1 & 1.189071 & 0.8799 \\
\hline 2 & 12.19913 & 0.0659 \\
\hline 3 & 16.30779 & 0.0726 \\
\hline 4 & 5.148712 & 0.2724 \\
\hline 5 & 0.593583 & 0.9638 \\
\hline 6 & 7.329295 & 0.1195 \\
\hline 7 & 5.986038 & 0.2002 \\
\hline 8 & 2.041305 & 0.7282 \\
\hline 9 & 4.341249 & 0.3618 \\
\hline 10 & 1.230112 & 0.8731 \\
\hline 11 & 1.334092 & 0.8556 \\
\hline 12 & 2.699603 & 0.6093 \\
\hline
\end{tabular}

Note: Probs from chi-square with $4 \mathrm{df}$.

\subsection{Variance Decompositions and Impulse Response Function}

We employ Variance Decompositions and Impulse Response Function to investigate the behavior of an error shock to each variable on its own future dynamics as well as on the future dynamics of the other variables in the VECM system. Variance decomposition measures the percentage of forecast error of variation that is explained by another variable within the short-run dynamics and interactions. The results of Variance Decompositions are presented in Table 7.

TABLE 7

The Results of Variance Decompositions

\begin{tabular}{c|c|c|c}
\hline & \multicolumn{3}{|c}{ Variance Decomposition of LCPI } \\
\hline Period & S.E. & LCPI & LIMPORT \\
\hline $\mathbf{1}$ & 0.007016 & 100.0000 & 0.000000 \\
\hline $\mathbf{2}$ & 0.009794 & 99.74821 & 0.251793 \\
\hline $\mathbf{3}$ & 0.011905 & 99.69839 & 0.301608 \\
\hline $\mathbf{4}$ & 0.013664 & 99.75602 & 0.243984 \\
\hline $\mathbf{5}$ & 0.015206 & 99.79658 & 0.203424 \\
\hline $\mathbf{6}$ & 0.016602 & 99.78309 & 0.216908 \\
\hline $\mathbf{7}$ & 0.017890 & 99.72971 & 0.270285 \\
\hline $\mathbf{8}$ & 0.019094 & 99.66077 & 0.339228 \\
\hline $\mathbf{9}$ & 0.020227 & 99.59332 & 0.406676 \\
\hline $\mathbf{1 0}$ & 0.021301 & 99.53515 & 0.464853 \\
\hline $\mathbf{1 1}$ & 0.022325 & 99.48790 & 0.512105 \\
\hline $\mathbf{1 2}$ & 0.023303 & 99.45035 & 0.549651 \\
\hline
\end{tabular}

\begin{tabular}{c|c|c|c}
\hline & \multicolumn{3}{|c}{ Variance } \\
\hline Period & S.E. & LCPI & LIMPORT \\
\hline $\mathbf{1}$ & 0.007016 & 0.000000 & 100.0000 \\
\hline $\mathbf{2}$ & 0.009794 & 0.121699 & 99.87830 \\
\hline $\mathbf{3}$ & 0.011905 & 0.543621 & 99.45638 \\
\hline $\mathbf{4}$ & 0.013664 & 1.354932 & 98.64507 \\
\hline $\mathbf{5}$ & 0.015206 & 2.552220 & 97.44778 \\
\hline $\mathbf{6}$ & 0.016602 & 4.029173 & 95.97083 \\
\hline $\mathbf{7}$ & 0.017890 & 5.638500 & 94.36150 \\
\hline $\mathbf{8}$ & 0.019094 & 7.263176 & 92.73682 \\
\hline $\mathbf{9}$ & 0.020227 & 8.840233 & 91.15977 \\
\hline $\mathbf{1 0}$ & 0.021301 & 10.34735 & 89.65265 \\
\hline $\mathbf{1 1}$ & 0.022325 & 11.78304 & 88.21696 \\
\hline $\mathbf{1 2}$ & 0.023303 & 13.15385 & 86.84615 \\
\hline
\end{tabular}

Figure 3 shows impulse responses. It shows the impact of a one standard deviation generalized innovation in the import on the inflation and a one standard deviation generalized innovation in the inflation on the import of Bangladesh. The effect of a shock to the import price on the inflation was positive throughout 12 month horizon where the effect of a shock to the inflation rate on the import became positive after $4^{\text {th }}$ period.

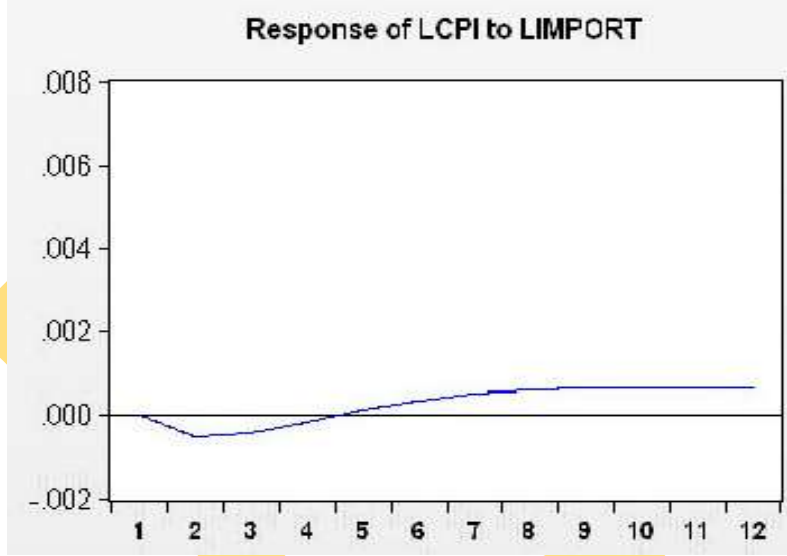

Fig. 3 (a). Impulse Response Function, LCPI to LIMPORT (Response to Cholesky One S.D. Innovations)

Response of LIMPORT to LCPI

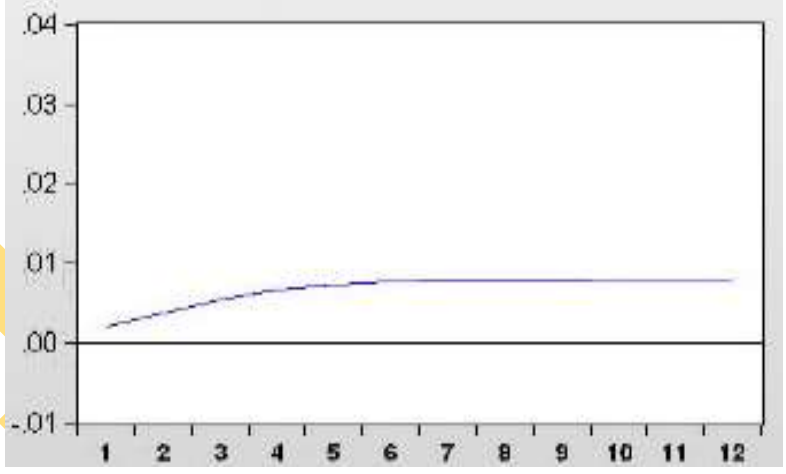

Fig. 3 (b). Impulse Response Function, LIMPORT to LCPI (Response to Cholesky One S.D. Innovations)

\subsection{Granger Causality Test}

Our final step of analysis is to test for causality between inflation and import. Granger causality is a technique for determining whether one time series is useful in forecasting another. A variable $(X)$ is said to Granger-cause another $(\mathrm{Y})$ if the present value of $\mathrm{Y}$ can be predicted with greater accuracy by using past values of $X$. If $X$ Grangercauses $Y$, then the causality from $X$ to $Y$ and If $Y$ Granger-causes $X$, then the causality from $Y$ to $X$. In both cases the causality is unidirectional. But when both variables Granger-cause each other, then it is called a bidirectional causality. We carry out granger causality test on series LCPI and LIMPORT with lag length 12 . The results are presented in Table 8. 
TABLE 8

Granger Causality Test

\begin{tabular}{|c|c|c|c|}
\hline Null Hypothesis & $\begin{array}{c}\text { F } \\
\text { Statistic }\end{array}$ & $\begin{array}{c}\text { P } \\
\text { Value }\end{array}$ & $\begin{array}{c}\text { Granger } \\
\text { Causality }\end{array}$ \\
\hline LIMPORT does not Grange Cause LCPI & 0.79436 & 0.6553 & No \\
\hline LCPI does not Granger Canse LIMPPORT & 2.78385 & $0.0024^{\cdots \cdots}$ & Yes \\
\hline
\end{tabular}

Note: i) No. of Obs. $=132$

ii) ${ }^{* * *}$ indicates statistically significant at the $1 \%$ level

Granger-causality results suggest that the null hypotheses that LCPI does not Granger cause LIMPORT is rejected at 1\% significant level which states that there is a uni-directional causality running from inflation to import. It affirms that the import does not have significant impact on inflation rather import is mostly affected by inflation.

\section{ConClusion}

This study attempts to investigate the relationship between inflation and import in Bangladesh for the period of 2000:01 to 2011:12 using different econometric frameworks. Our empirical result shows a stable, positive and significant relationship between inflation and import. Evidence from Granger causality analysis suggests there is existence of unidirectional causality running from inflation to import which indicates inflation lead import condition for the economy of Bangladesh.

The Bangladesh economy has to deal with inflationary pressure over many years. Higher import dependency is significantly attributed by domestic inflation. Our resources need to be utilized at optimal. Policymakers should concern about others factors like money supply, interest rate, exchange rate, exports, remittance, government expenditure which are also contributors to the genesis of the inflation of our country. Finally, if we can increase our production level as well as productivity to optimal then the upward pressure on domestic price level of goods can be checked. This will ultimately help to cut extensive import dependency which is necessary of achieving economic growth faster for the country.

\section{REFERENCES}

Abidemi, O. \& Malik, S. (2010). "Analysis of Inflation and its determinant in Nigeria". Pakistan Journal of Social Sciences, 7(2), 97100.

Begum, N. (1991). "A Model of Inflation for Bangladesh". Philippines Review of Economics and Business, 28 (1), 100-117.

Dexter, A.S., Levi, M.D. \& Nault, B.R. (2005). "International Trade and the Connection between Excess Demand and Inflation". Review of International Economics, 13 (4), 699-708.

Engle, R. \& Granger, C. (1987). “Co-integration and Error-correction: Representation, Estimation and Testing". Econometrica, 55, 251276.

Granger, C. (1986). "Developments in the Study of Cointegrated Economic Variables". Oxford Bulletin of Economics and Statistics, 48(3), 213-228.

Haque, S. \& Emran, M. (1992)." Specification Tests - A Case Study of Inflation in Bangladesh". Chittagong University Studies, Commerce, 8 .

Khan, R.E.A. \& Gill, A.R. (2010). “Determinants of Inflation: A Case of Pakistan (1970-2007)". Journal of Economics, 1 (1),45-51.

Khanam, R. \& Rahman, M. (1995). "The causative factors of inflation in Bangladesh-An Econometric Study". Chittagong University Studies, Social Science, 16 (1), 100-116.

Lim, C. \& Papi, L. (1997). "An Econometric Analysis of the determinants of Inflation in Turkey". IMF Working paper no. 170, pp 01-32.

Majumder, M. A. (2006). "Inflation in Bangladesh: Supply Side Effects". Policy Notes Series: PN 0705, Bangladesh Bank.

Taslim, M. (1982). "Inflation in Bangladesh: A Reexamination of the Structuralist-Monetarist Controversy". The Bangladesh Development Studies, 10 (1), 23-52.

Ulke, V. and Ergun, U. (2011). "Econometric Analysis of Import and Inflation Relationship in Turkey between 1995 and 2010". Journal of Economic and Social Studies, 1(2), 69-86. 